\title{
VAnishing Set-Aside Authority in International Commercial Arbitration
}

\author{
Meng Chen \\ Shenzhen University, Shenzhen, China \\ mchen63@szu.edu.cn \\ \& \\ Chengzhi Wang \\ Sun Yat-sen University Law School, China \\ wangchzh@mail.sysu.edu.cn
}

CHEN, Meng; WANG, Chengzhi Vanishing Set-Aside Authority in International Commercial Arbitration. International and Comparative Law Review, 2018, vol. 18, no. 1, pp. 127-154. DOI: 10.2478/iclr-2018-0029.

\begin{abstract}
Summary: Traditional set-aside theory is subject to considerable challenges as a result of an uncompromising trend towards autonomy and internationalism in international arbitration. The silence and ambiguity of international law regarding enforcement of set-aside arbitral awards allow some states to abandon their own set-aside authority or ignore set-aside decisions made by competent courts. This article presents a range of evidence that demonstrates the enforcement of set-aside arbitral awards has become a common phenomenon. This article first introduces robust academic debates regarding set-aside authority. Then this article exposes omission and ambiguity in the legal source, which leads to confusion in enforcement proceedings of set-aside arbitral awards. This article describes and analyses selected cases and practical data in order to summarize the approaches taken by national courts when reviewing foreign set-aside decisions. Finally, this article briefly evaluates the most promising solutions to the contradictory enforcement proceedings of set-aside arbitral awards.
\end{abstract}

Keywords: Set-aside authority, New York Convention, Set-aside arbitral awards, International commercial arbitration, Enforcement proceeding

\section{Introduction}

Set-aside authority is considered to be the most efficient supervision mechanism for the alleviation of potential unfairness and injustice in international commercial arbitration. ${ }^{1}$ However, traditional set-aside authority is subject to considerable challenges as a result of an uncompromising trend towards

1 Reisman, W. Michael. System of Control in International Adjudication and Arbitration Breakdown and Repair. Duke University Press Durham and London, 1992, pp. 127-8. 
autonomy and internationalism in international arbitration. Commentators have questioned the rationality of establishing set-aside authority. If relevant evidence demonstrates that it is usual for enforcement courts to examine foreign set-aside decisions and to enforce arbitral awards that have been set aside based on grounds that are not provided by national law of enforcement states, pursuing strict set-aside theory seems, regrettably, to be an illusion. This article presents a range of evidence to reveal that the silence and ambiguity of international and national provisions regarding enforcement of set-aside arbitral awards increases tendency for some states to ignore set-aside decisions that have been made by foreign national courts. Despite emerging unified approaches in adopting international standards for recognizing foreign set-aside decisions, empirical data in this study demonstrates how contradictory enforcement proceedings of set-aside arbitral awards leads to significant confusion and severe problems in arbitral practice. Consequently, after concluding approaches taken by enforcement courts from different jurisdictions when granting or refusing enforcement of set-aside arbitral, this article attempts to propose a number of solutions to this problem.

\section{Academic debate and legal sources}

\subsection{Academic debates regarding set-aside authority}

Two jurisdictions are seated at vital positions for the execution of effective judicial supervision at the post-award stage, the first being the 'primary jurisdiction', where the arbitration is held, and the second being the 'secondary jurisdiction', where the arbitral award is enforced. ${ }^{2}$ In traditional 'seat' theory ${ }^{3}$, national courts at primary jurisdiction are entitled to set aside arbitral awards, which invalidates the awards per se and make them unenforceable everywhere, while the secondary jurisdiction can only refuse to recognize or enforce arbitral awards. Thus, many academics contend that the authority of primary jurisdictions to set aside arbitral awards is the most effective mechanism for the supervision of the international arbitration process. ${ }^{4}$ Based on this consideration, many international and national laws prescribe the authority of national courts at primary jurisdiction and grounds for setting aside arbitral awards.

Even though the significance of primary jurisdiction has been emphasized for many decades, it is subject to many challenges. For example, the theory of 'delocalization' attempts to eliminate the 'nationality' of international arbitration and create a so-called 'floating' arbitration that has a limited relationship with the physical place of arbitration. ${ }^{5}$ Extreme Delocalization school aims to elimi-

2 Idid.

3 Mann, F.A., Arbitrum, Lex Facit. International Arbitration: Liber Amicorum for Martin Domke. 1967, pp. 157-9.

4 See Reisman, supra note 1.

5 Poudret, Jean-François, Besson, Sébastien. Comparative Law of International Arbitration. 
nate or limit the authority of national courts to set aside arbitral awards that are rendered in their jurisdiction. ${ }^{6}$ Delocalization of the award indicates that nullity decisions made by courts at the place of arbitration shall not have a global effect. Under an extreme interpretation of delocalization theory, an annulment decision made by a local court or a decision to set aside an award would have no effect on the likelihood of enforcement in other jurisdictions. ${ }^{7}$ The trend towards delocalization has had profound impact on a variety of court decisions ${ }^{8}$ and national legislation, ${ }^{9}$ as well as on international rules. ${ }^{10}$ 'Primary jurisdiction' and 'delocalization' theories represent two extremes of an ideological trend that is entrenched in the spirit of arbitration system. Both theories, each very different to the other, have had a profound influence on the development of international commercial arbitration.

Discussion of set-aside authority is complicated because it must include not only how state courts set aside arbitral awards rendered in their territory, it must also include what kind of effect an enforcement court will confer to a set-aside decision made by a foreign court. ${ }^{11}$ From the systematizer's perspective, set-aside authority has a worldwide effect to work as a brake for all enforcement process of an arbitral award. However, many commentators have pointed out that the design of primary jurisdiction is based on the premise that the arbitral award is set aside for 'good' reason. ${ }^{12}$ Considering the grounds for setting aside arbitral awards lies primarily in the sphere of national laws, and judicial practice in many states is unpredictable; the assumption that all (or even most) set-aside decisions are made 'correctly' seems unduly idealistic. Advocates have supplemented various argumentations for recognizing set-aside decisions made by competent

Sweet\&Maxwell, 2007, pp. 120-34; Redfern, Hunter. Redfern and Hunter on International Arbitration. Oxford University Press, 5th Ed., 2009, pp. 188-91; Rubino-Sammartano, Mauro. International Commercial Arbitration. Kluwer Law and Taxation Publishers, 1990, pp. 283-98; P. Mayer. The Trend Towards Delocalisation in the last 100 Years, in Graham, Trotman/M. Nijhoff, The Internationalisation of International Arbitration: The LCIA Centenary Conference. Graham \& Trotman/M. Nijhoff,, 1995, pp. 37-48; PARK, William W. Judicial Controls in the Arbitral Process. Arb. Int'l. 1989, vol.5 p.279; PARK, William W. The Lex Loci Arbitri and International Commercial Arbitration. I.C.L.Q., 1983, vol. 32, p.2.

6 Chukwumerije, Okezie. Choice of Law in International Commercial Arbitration. 1994, p. 89.

7 Read, Pippa. Delocalization of International Commercial Arbitration: It's Relevance in the New Millennium. Am. Rev. Int'l Arb., 1999, vol. 10, p. 186.

8 See Read, supra note 7, p. 192 n. 55.

9 See Reisman, supra note 1, p. 126.

10 Derains, Yves, Schwarts, Eric A. A guide to the new ICC rules of Arbitration. Kluwer Law International, 2005, p.209.

11 Scherer, Maxi. The Effect of Foreign National Court Judgments Relating to the Arbitral Award: An Emerging Conceptual Framework? in Menaker, Andrea (ed). International Arbitration and the Rule of Law: Contribution and Conformity. Kluwer Law International, 2017, pp. 691-705.

12 Lastenouse, Pierre. Why Setting Aside an Arbitral Award is not Enough to Remove it from the International Scene. Journal of International Arbitration, 1999, vol. 16, p. 25. 
courts, including interest of the seat, expectation of parties and comity in recognizing foreign judgments and so on. ${ }^{13}$ None of these argumentations provides an overriding and pervasive deference to strict set-aside authority at the enforcement stage. ${ }^{14}$ Commentators have pointed out that the New York Convention does not require that enforcement courts refuse enforcement of set-aside arbitral awards, especially when these awards have been set aside based on 'local standards. ${ }^{15}$ A number of cases have demonstrated that courts in various jurisdictions have taken varying approaches when dealing with arbitral awards that have been set aside by competent courts. ${ }^{16}$ In particular, when bribery, fraud and other violations of 'international public policy' are suspected in the set-aside decisions of foreign courts, it is difficult to expect all other enforcement courts to be willing to confer full credit to such set-aside decisions. ${ }^{17}$ Ironically, national judges may believe that the set-aside decisions made by their own courts should invalidate arbitral awards per se, but their national courts inevitably harbor an incredulous attitude towards set-aside decisions made by foreign courts. Even though there is no violation of international public policy in setting aside proceedings, following a detailed analysis of empirical data, we find that, as long as suspicion exists, enforcement courts intend to make a comprehensive examination of both foreign set-aside decisions and relevant arbitral awards in order to make enforcement or refusal decisions. Confusing argumentations and redundant proceedings gradually corrupt the effectiveness of international arbitration proceedings. In summary, the theoretical two-tier supervision mechanism is unrealistic in practical terms.

\subsection{Relevant international provisions}

The most widely discussed international provisions regarding the enforcement of set-aside arbitral awards are provided in the New York Convention and the UNCITRAL Model Law on International Commercial Arbitration. Article V 1(e) of the New York Convention states that enforcement courts 'may' refuse to

13 Gaillard, E. The Enforcement of Awards Set Aside in the Country of Origin. ICSID Rev., 1999, vol. 14, p.16; Paulsson, J. Enforcing Arbitral Awards notwithstanding a Local Standard Annulment (LSA). ICC International Court of Arbitration Bulletin, 1998, vol. 9, no. 1, p.14; Park, W. Duty and Discretion in International Arbitration. Am J. Int'l L., 1999, vol. 93, p.805; Koch, Christopher. The Enforcement of Awards Annulled in their Place of Origin: The French and US experience. J. Int'l Arb., 2009, vol. 26, p.292; Dunmore, Michael. Chapter III: The Award and the Courts, Enforcement of Awards Set Aside in their Jurisdiction of Origin', in Klausegger, Christian, Klein, Peter, et al. (eds). Austrian Yearbook on International Arbitration 2014. 2014, pp. 285-315.

14 Radicati di Brozolo, Luca G. The Present-Commercial Arbitration as a Transnational System of Justice, in Jan Van Den Berg, Albert (ed). Arbitration: the Next Fifty Years, ICCA Congress Series. Kluwer Law International, 2012, p. 96.

15 See Paulsson, supra note 13.

16 See Dunmore, supra note 13; Koch, supra note 13.

17 Berger, Klaus Peter. Private Dispute Resolution in International Business: Negotiation, Mediation, Arbitration. Kluwer Law International, 2015, p. 664. 
enforce arbitral awards that have been set aside. ${ }^{18}$ Many scholars point out that the New York Convention neither compels enforcement courts to refuse set-aside arbitral awards nor provides grounds for such refusal. ${ }^{19}$ Similarly, Article 34 of the UNCITRAL Model Law provides detailed grounds for setting aside arbitral awards, and Article 36 (1) (a) (v) provides similar grounds for refusing enforcement. ${ }^{20}$ The exclusive grounds for setting aside arbitral awards that are provided in Article 34 of the UNCITRAL Model Law mirror the grounds for refusing enforcement that are provided in both the UNCITRAL Model Law and the New York Convention. Similar grounds for refusing enforcement can also be found in Article 5.1 e of the Inter-American Convention on International Commercial Arbitration (Panama Convention), which provides that courts 'may' refuse to enforce arbitral awards that have been set aside. ${ }^{21}$ Therefore, these international provisions take an ambiguous approach regarding whether enforcement courts should refuse to enforce arbitral awards that have been set aside.

Other international treaties attempt to unify the grounds for setting aside arbitral awards. For example, Article IX of the 1961 European Convention on International Commercial Arbitration (hereinafter, the European Convention of 1961) stipulates four grounds for setting aside arbitral awards; these four grounds were modeled on the grounds for refusing enforcement that are provided in Article V(1)(a)-(d) of the New York Convention. ${ }^{22}$ The four grounds exclude public policy and arbitrability provisions that are provided in Article $\mathrm{V}$ (2) of the New York Convention and Article 34 of the UNCITRAL Model Law. Therefore, Article IX of the European Convention of 1961 imposes more limitations on set-aside authority and implies that enforcement courts shall not accord preclusive effect to set-aside decisions based on other grounds that are not provided in this Article. ${ }^{23}$

181958 Convention on the Recognition and Enforcement of Foreign Arbitral Awards [hereinafter New York Convention], 330 UNTS 38, Art. V (1) (e), '1. Recognition and enforcement of the award may be refused, at the request of the party against whom it is invoked, only if that party furnishes to the competent authority where the recognition and enforcement is sought, proof that:.... (e) The award has not yet become binding on the parties, or has been set aside or suspended by a competent authority of the country in which, or under the law of which, that award was made.'

19 Bird, Robert C. Enforcement of Annulled Arbitration Awards: A Company Perspective and an Evaluation of a "New" New York Convention. N.C. J. Int'l L. \& Com. Reg., 2012, vol. 37, p. 1028.

20 UNCITRAL Model Law on International Commercial Arbitration (1985) with amendments as adopted in 2006 [hereinafter UNCITRAL Model Law], U. N. Sales No. E.08.V.4 (2008). Art. 34 \& 36 (1) (a) (v).

211975 Inter-American Convention on International Commercial Arbitration [hereinafter Panama Convention], 14 I.L.M. 336 (1975), Art. 5.1 e.

221961 European Convention on International Commercial Arbitration of 1961 [hereinafter European Convention of 1961], 484 UNTS 364 No. 7041.

23 See European Convention of 1961, Art. IX (2), supra note 22. 
Even though some international provisions stipulate grounds for setting aside arbitral awards, none of them confirm the effect of nullity of set-aside decisions, which leaves great discretion with the enforcement courts. Without clear and coercive international resources, national courts will continue to enforce or refuse to enforce set-aside arbitral awards based on their own interpretation of international rules and relevant national legislation.

\subsection{National legislation}

The framework of set-aside authority includes the following two issues: (i) the grounds for a state court to set aside an arbitral award, and (ii) how a state court treats an arbitral award that has been set aside in its country of origin ${ }^{24}$. In order to elaborate on the varied approaches taken by different jurisdictions for enforcing set-aside arbitral awards, this section begins by analyzing and comparing national legislation regarding setting aside arbitral awards in twelve states. These states are generally considered to be popular places of arbitration or enforcement. All twelve states are signatories to the New York Convention. This research studies their national provisions regarding setting aside authority, grounds for setting aside arbitral awards, whether they allow parties to waive setting aside authority, and whether they require courts to refuse enforcement of arbitral awards that have been set aside.

This article demonstrates that, even though set-aside authority is commonly stipulated in national provisions, and most states stipulate detailed grounds for setting aside arbitral awards, some states show less interest in intervening in arbitration taking place in their territories. After the New York Convention entered into force, two states, Belgium and Switzerland, driven by the desire to attract more arbitration business, revised their arbitration legislation so as to release their courts from the obligation to supervise international arbitrations taking place in their territories. ${ }^{25}$ Article 1718 of the Belgian Judicial Code stipulates the following: By an explicit declaration in the arbitration agreement or by a later agreement, the parties may exclude any application for the setting aside of an arbitral award, where none of them is a natural person of Belgian nationality or a natural person having his domicile or normal residence in Belgium or a legal person having its registered office, its main place of business or a branch office in Belgium. ${ }^{26}$

One scholar points out that the failure of states to execute their supervisory responsibility as primary or secondary jurisdictions will considerably enhance the burden of the losing party in international arbitration and other competent jurisdictions, even though unjustified arbitral awards may not eventually be

24 See Koch, supra note 13.

25 See Reisman, supra note 1.

26 Paulsson, Jan, Bosman, Lise (eds). ICCA International Handbook on Commercial Arbitration. 2013, Supplement No. 45, pp.1-16. 
enforced. ${ }^{27}$ Although the actual application rate of these provisions is unclear in practice, it is highly possible that if other states and the arbitration community come to believe that Belgium and Switzerland successfully attracted profitable arbitration business by failing to fulfill their responsibilities or promulgating arbitration friendly laws, other states may simply copy their behavior and externalize supervision costs and responsibility to the disputants and other jurisdictions. ${ }^{28}$ This possibility seems to have been realized when one considers the similar approaches that are followed in Article 1522 of the French Code of Civil Procedure, ${ }^{29}$ and Section 51 of the Sweden Arbitration Act of 1999.

On the contrary, national provisions regarding enforcement of arbitral awards that have been set aside in their country of origin seem to be more uniform. This research does not distinguish grounds for refusing enforcement of arbitral awards based on pure national legislation or on the New York Convention. Because all of these states are signatories to the New York Convention, it is very likely that their legislation is modeled on the New York Convention. This article compares relevant provisions collected from arbitration codes, civil procedural laws and other forms of legislation promulgated by these states. Germany, Switzerland and the Unites States are exceptions to the other states. Germany and Switzerland do not provide pure national provisions regarding the enforcement of international arbitral awards that have been set aside. Their legislation directly quotes the New York Convention for governing the enforcement of foreign arbitral awards. Furthermore, it is controversial whether the United States Federal Arbitration Act provides exclusive grounds for refusing enforcement of international arbitral awards. ${ }^{30}$ Some outdated grounds, which are established in case law, are frequently arouse in practice, for example the notorious 'manifest disregard of law' doctrine. ${ }^{31}$ For completeness of the comparison, this article presumes that Article V of the New York Convention constituted the relevant legislation of Germany, Switzerland and United States. Exceptional states are marked with '*' under the column 'Refuse enforcement of set-aside arbitral awards' in the following table.

This article finds that most states stipulate that national courts 'may' refuse enforcement of arbitral awards that have been set aside, following the Article V

27 See Reisman, supra note 1.

28 See Reisman, supra note 1.

29 Paulsson, Jan, Bosman, Lise. ICCA International Handbook on Commercial Arbitration. 2011, Supplement No. 43, p. 13.

30 It is controversial whether United States Federal Arbitration Act or the New York Convention provide exclusive grounds for refusing enforcement of international arbitral awards in United States. The latest Hall Street decision made by the U.S. Supreme Court held that the standards for judicial review of an arbitral award set forth in Sections 10 and 11 of the Federal Arbitration Act ('FAA') are exclusive and may not be expanded by contract. See Hall Street Associates, L.L.C. v. Mattel, Inc., 128 S. Ct. 1396 (U.S. 2008).

31 Scodro, Michael A. Deterrence and Implied Limits on Arbitral Power. Duke L. J., 2005, vol. 55 , p.557. 
of the New York Convention. China, Sweden, and Italy require that their courts refuse enforcement if arbitral awards are set aside by competent courts. ${ }^{32}$ France is the only state that provides 'being set aside' is not a legal ground for refusing enforcement of an international arbitral award in its national law. ${ }^{33}$ This research indicates that the New York Convention is interpreted inconsistently by different states, and that most national legislation fails to support the nullity effect of setaside authority strictly.

In brief, most national legislation provides grounds for setting aside arbitral awards without requiring national courts to follow foreign set-aside decisions. Furthermore, some states even allow parties to contract out of set-aside authority. A summary of the analysis is presented in the following table.

\begin{tabular}{|c|c|c|c|c|}
\hline States & $\begin{array}{l}\text { Set-aside } \\
\text { authority }\end{array}$ & $\begin{array}{c}\text { Grounds for } \\
\text { setting aside } \\
\text { arbitral awards }\end{array}$ & $\begin{array}{l}\text { Waiving set- } \\
\text {-aside authority }\end{array}$ & $\begin{array}{c}\text { Refuse } \\
\text { enforcement } \\
\text { of set-aside } \\
\text { arbitral awards }\end{array}$ \\
\hline United Kingdom (1) & Yes & Not provided & Not provided & May \\
\hline France (2) & Yes & $\begin{array}{l}\text { Code of Civil } \\
\text { Procedure, } \\
\text { Article } 1520\end{array}$ & $\begin{array}{l}\text { Code of Civil } \\
\text { Procedure, } \\
\text { Article } 1522\end{array}$ & Not provided \\
\hline Germany (3) & Yes & $\begin{array}{l}\text { German Arbit- } \\
\text { ration Act 1998, } \\
\text { Section } 1059\end{array}$ & Not provided & $\mathrm{May}^{*}$ \\
\hline Belgium (4) & Yes & $\begin{array}{c}\text { Part VI of the } \\
\text { Belgian Judicial } \\
\text { Code on Arbitra- } \\
\text { tion, Article } 1717\end{array}$ & $\begin{array}{c}\text { Part VI of the } \\
\text { Belgian Judicial } \\
\text { Code on Arbitra- } \\
\text { tion, Article } 1718\end{array}$ & May \\
\hline Netherlands (5) & Yes & $\begin{array}{l}\text { The Arbitration } \\
\text { Act, Code of } \\
\text { Civil Procedure, } \\
\text { Article } 1065\end{array}$ & Not provided & May \\
\hline Switzerland (6) & Yes & $\begin{array}{c}\text { Private Internati- } \\
\text { onal Law Statute, } \\
\text { Article } 190\end{array}$ & $\begin{array}{c}\text { Private Internati- } \\
\text { onal Law Statute, } \\
\text { Article } 192\end{array}$ & $\mathrm{May}^{*}$ \\
\hline Italy (7) & Yes & $\begin{array}{l}\text { Code of Civil Pro- } \\
\text { cedure Article } 829\end{array}$ & Not provided & $\begin{array}{c}\text { Shall, Code of } \\
\text { Civil Procedure } \\
\text { Article } 840\end{array}$ \\
\hline Sweden (8) & Yes & $\begin{array}{l}\text { The Arbitration Act } \\
\text { of } 1999 \text {, Section } 34\end{array}$ & $\begin{array}{l}\text { The Arbitration Act } \\
\text { of } 1999 \text {, Section } 51\end{array}$ & $\begin{array}{l}\text { Shall, The Arbi- } \\
\text { tration Act of } \\
\text { 1999, Section } 54\end{array}$ \\
\hline Australia (9) & Yes & Not provided & Not provided & May \\
\hline New Zealand (10) & Yes & $\begin{array}{l}\text { Arbitration Act } \\
\text { 1996, Article } 34\end{array}$ & Not provided & May \\
\hline
\end{tabular}

32 China, Sweden and Italy, see following chart. The conclusion was made based on English translation of original laws.

33 Article 1525 of French Code of Civil Procedure, see PAULSSON, Jan, BOSMAN, Lise. ICCA International Handbook on Commercial Arbitration. 2011, Supplement No. 64, p. 4. 
ICLR, 2018, Vol. 18, No. 1.

\begin{tabular}{|c|c|c|c|c|}
\hline United States (11) & Yes & $\begin{array}{c}\text { Federal Arbitration } \\
\text { Act Section 10 }\end{array}$ & Not provided & May $^{*}$ \\
\hline China (12) & Yes & $\begin{array}{c}\text { Arbitration Law } \\
\text { of The People's } \\
\text { Republic of China, } \\
\text { Article 58 }\end{array}$ & $\begin{array}{c}\text { Shall, Arbitration } \\
\text { Law of The Peo- } \\
\text { ple's Republic of } \\
\text { China, Article 63 }\end{array}$ \\
\hline $\begin{array}{c}\text { New York } \\
\text { Convention }\end{array}$ & Yes & Not provided & Not provided & $\begin{array}{c}\text { May, Article } \\
\text { V 1 (e) }\end{array}$ \\
\hline $\begin{array}{c}\text { UNCITRAL } \\
\text { Model Law }\end{array}$ & Yes & Article 34 & Not provided & $\begin{array}{c}\text { May, Article } \\
36(1)(\mathrm{a})(\mathrm{v})\end{array}$ \\
\hline
\end{tabular}

(1) PAULSSON, Jan, BOSMAN, Lise. ICCA International Handbook on Commercial Arbitration. 1997, Supplement No. 23, pp. 1-50.

(2) PAULSSON, Jan, BOSMAN, Lise. ICCA International Handbook on Commercial Arbitration. 2011, Supplement No. 64, pp. 1-16.

(3) PAULSSON, Jan, BOSMAN, Lise. ICCA International Handbook on Commercial Arbitration. 2009, Supplement No. 55, pp. 1-14.

(4) PAULSSON, Jan, BOSMAN, Lise. ICCA International Handbook on Commercial Arbitration. 2013, Supplement No. 77, pp. 1-16.

(5) PAULSSON, Jan, BOSMAN, Lise. ICCA International Handbook on Commercial Arbitration. 2015, Supplement No. 83, pp. 1-26.

(6) Gaillard, Emmanuel, Savage, John (eds.). Fouchard, Gaillard, Goldman, On International Commercial Arbitration, 1999, p. 1025.

(7) PAULSSON, Jan, BOSMAN, Lise. ICCA International Handbook on Commercial Arbitration. 2007, Supplement No. 49, pp.1-16.

(8) PAULSSON, Jan, BOSMAN, Lise. ICCA International Handbook on Commercial Arbitration. 2000, Supplement No. 32, pp. 1-16

(9) PAULSSON, Jan, BOSMAN, Lise. ICCA International Handbook on Commercial Arbitration. 2012, Supplement No. 70, pp. 1-26.

(10)PAULSSON, Jan, BOSMAN, Lise. ICCA International Handbook on Commercial Arbitration. 2011, Supplement No. 63, pp. 1-35.

(11)1925 Federal Arbitration Act $\$ 10$ [hereinafter FAA], 9 U.S.C. $\$ 1$.

(12)PAULSSON, Jan, BOSMAN, Lise. ICCA International Handbook on Commercial Arbitration 1994, Supplement No. 18, pp. 1-12

\section{Confusing national enforcement proceedings}

Inconsistent national set aside grounds and ambiguous rules on enforcement of set-aside arbitral awards lead to great confusion in national enforcement proceedings. Three iconic cases are now presented in detail in order to compare the approaches taken by national courts for enforcing set-aside arbitral awards. All three cases involved arbitral awards that were set aside by competent courts, and that were sought for enforcement in two other states. It is interesting to examine the reasoning of different national courts that faced the same case facts. These cases manifested that, besides the well-known French approach of applying 'more-favorable' national standards, the English, United States and Dutch courts all intended to review foreign set-aside decisions based on their own national legislation and public policy. Even though enforcement states did provide being set aside as a ground for refusing enforcement, the divergent understanding of 
enforcement judges regarding public policy, due process or governing law, and so forth, may eventually trigger the application of the 'more-favorable-right' provision or convince judges to ignore foreign set-aside decisions. Three cases further evidence that most states are irresolute on the issue of enforcing set-aside awards. Noticeably, the reasoning of national courts in two recent cases, namely PEMEX and Nikolai, varied widely from previous iconic cases such as Hilmarton and Chromalloy. With enforcement courts insisting that they have the discretion to grant or refuse enforcement of arbitral awards that have been set aside in their countries of origin, these courts also tend to believe that this discretion is limited to rare circumstances whereby relevant foreign set-aside decisions were 'extreme incorrect' and violate 'international public policy.' ${ }^{34}$ Specifically, the Dutch courts offered a practical approach to implement the somewhat abstract concept of 'international public policy' by adopting Art. 6 of the European Convention on Human Rights (ECHR) to demonstrate due process standards. ${ }^{35}$

Two other cases, Nikolai and Yukos, proceeded along a similar enforcement path. They both involved enforcement of arbitral awards that had been set aside by Russian courts and afterwards were sought for enforcement in the UK and Netherlands. All the involved enforcement courts were faced by arguments that the set-aside decisions of the Russian courts were made in bad faith and, thus, should be disregarded due to violation of public policy. ${ }^{36}$ Disregarding their factual differences, a comparison between their opposing enforcement decisions revealed that enforcement judges started to sustain their suspicion and give more credit to foreign set-aside decisions. Even though it is rather early to conclude debates regarding the enforcement of set-aside arbitral awards, a number of national enforcement courts are gradually forming consistent judicial practice by adopting more internationalized standards.

\subsection{PEMEX: Mexico, United States, \& the Luxembourg ${ }^{37}$}

On October 22, 1997, PEMEX Exploración y Producción (hereinafter "PEP”) entered into several contracts with Corporación Mexicana de Mantenimiento Integral, S. de R.L. de C.V. (hereinafter "COMMISA"), which included an arbitration clause providing for arbitration under the ICC Arbitration Rules; the place of the arbitration was Mexico and the applicable law was Mexican law. After disputes arose, COMMISA commenced an arbitration with the ICC. In spite of PEP's challenge to arbitral jurisdiction, on December 16, 2009, the ICC arbitral tribunal rendered the final award in favor of GOMMISA. On January 11, 2010, COMMISA sought enforcement of the ICC award before the N.Y. District Court. On April 5, 2010, PEP moved to dismiss the petition or, alternatively, for a stay

34 See following Nikolai and Yukos.

35 Jan Van Den Berg, Albert. Yearbook Commercial Arbitration. 2013, Vol.38, pp. 427-30.

36 Jan Van Den Berg, Albert. Enforcement of arbitral awards annulled in Russia. Journal of International Arbitration, 2010, vol. 27, p.179.

37 Jan Van Den Berg, Albert. Yearbook Commercial Arbitration. 2017, Vol.42, pp.1-3. 
pending resolution of its efforts to set aside the award in Mexico. The petition was granted by the N.Y. District Court. Concurrently, PEP filed applications to several Mexican courts for setting aside the award. An appellate court, the Fifth District Court, subsequently annulled the Award.

COMMISA sought enforcement of the Mexican Award in both the United States and Luxembourg. After several court proceedings in the United States, on August 2, 2016, the Second Circuit held that the District Court correctly exercised its discretion to enforce the annulled award.

In Luxembourg, on April 27, 2017, the Eighth Chamber of the Court of Appeal reversed Luxembourg District Court's enforcement decision, holding that an award that has been set aside in the country of rendition cannot be granted recognition and enforcement under the 1958 New York Convention. Relevant courts' reasoning are concluded in following table:

\begin{tabular}{|c|c|c|}
\hline $\begin{array}{l}\text { Mexican Courts } \\
\text { (Set aside courts) }\end{array}$ & $\begin{array}{l}\text { Luxembourg Courts } \\
\text { (Enforcement courts) }\end{array}$ & US Courts (Enforcement courts) \\
\hline $\begin{array}{l}\text { ICC arbitral award vio- } \\
\text { lated Mexican public } \\
\text { policy because the ter- } \\
\text { mination of the public } \\
\text { contracts (rescisión } \\
\text { administrativa) was } \\
\text { "issued to safeguard } \\
\text { financial resources" } \\
\text { of the Mexican State. }\end{array}$ & $\begin{array}{l}\text { The Court of Appeal dismissed } \\
\text { COMMISA's argument that the } \\
\text { Mexican annulment decision } \\
\text { violated public policy and thus } \\
\text { could not be recognized as a } \\
\text { means to establish that the Award } \\
\text { had been annulled. The Court } \\
\text { confirmed if the award has been } \\
\text { annulled or suspended by a } \\
\text { competent authority, and thus } \\
\text { produces no effects in its country } \\
\text { of origin, the decision to deny } \\
\text { recognition and enforcement of } \\
\text { such award is justified under both } \\
\text { the } 1958 \text { New York Convention } \\
\text { and Art. } 1251 \text { of the New Code of } \\
\text { Civil Procedure of Luxembourg. }\end{array}$ & $\begin{array}{l}\text { Southern District Court of New } \\
\text { York held that the relevant judicial } \\
\text { proceedings that took place in } \\
\text { Mexico deprived COMMISA of } \\
\text { fundamental due process rights, } \\
\text { and thus violated basic notions of } \\
\text { justice. In this decision, the U.S. } \\
\text { judge quoted provisions regarding } \\
\text { the public policy doctrine in both } \\
\text { the Inter-American Convention } \\
\text { on International Commercial } \\
\text { Arbitration (Panama Convention) } \\
\text { and the New York Convention. }\end{array}$ \\
\hline
\end{tabular}

\subsection{Nikolai: Russia, United Kingdom \& the Netherlands}

By a Purchase Agreement of November 22, 2007, Mr. Nikolai Viktorovich Maximov sold Open Joint Stock Company "Novolipetsky Metallurgichesky Kombinat" (NLMK) 50 percent plus one of his shares in the capital of OJSC Maxi-Group (Maxi-Group). The agreement contain an arbitration clause for arbitration of disputes at the International Commercial Arbitration Court (ICAC) at the Chamber of Commerce and Industry of the Russian Federation (CCI). On December 2, 2009, Maximov commenced ICAC arbitration, seeking payment of the balance of the shares' purchase price. The arbitral tribunal rendered an arbitral award on March 31, 2011. In the Russian Federation, NLMK filed an action with the Arbitrazh (Commercial) Court in the City of Moscow on 
April 7, 2011, seeking annulment of the ICAC award. On October 10, 2011, the Federal Arbitrazh Court in Moscow annulled the award.

Maximov sought recognition and enforcement of the ICAC award in France, the Netherlands and the United Kingdom. In France, his application was eventually denied by the French Supreme Court. In Netherlands, the Amsterdam Court of Appeal denied enforcement of the ICAC award under Art. V (1) (e) of the New York Convention in a final decision of September 27, 2016. In the United Kingdom, the High Court dismissed Maximov's application for recognition and enforcement, holding that the award had been annulled and that there was no reason to disregard the Russian annulment decisions as being the result of bias, notwithstanding the Court's 'severe criticism' thereof. Relevant courts' reasoning are concluded in following table:

\begin{tabular}{|c|c|c|}
\hline $\begin{array}{l}\text { Russian Courts (Set } \\
\text { aside courts) }\end{array}$ & $\begin{array}{l}\text { Netherlands Courts } \\
\text { (Enforcement courts) }\end{array}$ & $\begin{array}{l}\text { UK Courts (Enfor- } \\
\text { cement courts) }\end{array}$ \\
\hline $\begin{array}{l}\text { Russian judge held that } \\
\text { two of the ICAC arbitrators } \\
\text { failed to disclose that, as } \\
\text { employees of the same legal } \\
\text { institutes that employed } \\
\text { two of Maximov's expert } \\
\text { witnesses, they were in a } \\
\text { subordinate position to them; } \\
\text { as a result, the composition } \\
\text { of the arbitral tribunal was } \\
\text { not in accordance with the } \\
\text { parties' agreement. She also } \\
\text { indicated dispute decided } \\
\text { in the award concerned the } \\
\text { validity of a share transfer } \\
\text { and was therefore not arbi- } \\
\text { trable under Russian law, and } \\
\text { that the method by which } \\
\text { the arbitrators determined } \\
\text { the purchase price was } \\
\text { contrary to mandatory Rus- } \\
\text { sian law on purchases. (1) }\end{array}$ & $\begin{array}{l}\text { While an annulled award } \\
\text { should be denied enforcement } \\
\text { in principle, the annulment } \\
\text { decision may be disregarded } \\
\text { where there are such strong } \\
\text { indications that the annulment } \\
\text { case was not heard fairly to } \\
\text { overcome the presumption of } \\
\text { the impartiality of the foreign } \\
\text { court. The Amsterdam Court } \\
\text { of Appeal denied enforcement } \\
\text { of the ICAC award under Art. } \\
\text { V (1) (e) of the New York } \\
\text { Convention, finding that there } \\
\text { was no reason to disregard the } \\
\text { Russian annulment decisions, } \\
\text { which did not constitute an } \\
\text { unfair trial under Art. } 6 \text { of } \\
\text { the European Convention on } \\
\text { Human Rights (ECHR). (2) }\end{array}$ & $\begin{array}{l}\text { The parties essentially agreed } \\
\text { that the proper test to apply to } \\
\text { decide whether to disregard } \\
\text { the Russian annulment } \\
\text { decisions was whether those } \\
\text { decisions"were so extreme and } \\
\text { incorrect as not to be open to } \\
\text { a Russian court acting in good } \\
\text { faith". Hence, the decisions } \\
\text { had to be deliberately wrong, } \\
\text { not simply wrong by incom- } \\
\text { petence. Also the relevant } \\
\text { evidence had to be cogent. (3) }\end{array}$ \\
\hline
\end{tabular}

(1) JAN VAN DEN BERG, Albert. Yearbook Commercial Arbitration. 2017, Vol.42, pp. 1-43.

(2) JAN VAN DEN BERG, Albert. Yearbook Commercial Arbitration. 2013, Vol.38, pp. 427-30.

(3) JAN VAN DEN BERG, Albert. Yearbook Commercial Arbitration. 2017, Vol.42, pp. 1-43.

\subsection{Yukos: Russia, United Kingdom \& the Netherlands}

In Yukos Capital S.A.R.L. v. OJSC Rosneft Oil Company (hereinafter 'Yukos'), Yukos Capital S.A.R.L. (Yukos Capital) and the Russian company OJSC entered into four loan agreements, which included an arbitration agreement providing for arbitration of disputes at the International Commercial Arbitration Court at 
the Chamber of Commerce and Industry of the Russian Federation (ICAC) ${ }^{38}$ After disputes arose, Yukos Capital commenced ICAC arbitration in the Russian Federation. On September 19, 2006, an ICAC arbitral tribunal rendered four awards in favor of Yukos Capital for an amount of approximately US\$ 425 million. On May 23, 2007, the Arbitrazh (Commercial) Court of the City of Moscow then granted an annulment of arbitral awards based on the finding that the loan agreements were illegal. ${ }^{39}$ Yukos Capital then sought enforcement of the ICAC awards in the Netherlands, where Rosneft had assets. On February 28, 2008, the President of the Amsterdam Court of First Instance denied enforcement under the New York Convention based on the awards that had been set aside in Russia. On April 28, 2009, the Court of Appeal of Amsterdam reversed the lower court's decision and granted enforcement. ${ }^{40}$

On March 11, 2010, Yukos Capital sought enforcement of the ICAC awards and post-award interest in the High Court of Justice of England and Wales. Rosneft rebutted, again based on the decision of the Russian courts to set aside the award. On July 3, 2014, the High Court made a decision to enforce the ICAC awards. ${ }^{41}$ Relevant courts' reasoning are concluded in following table:

\begin{tabular}{|c|c|c|}
\hline $\begin{array}{l}\text { Russian Courts } \\
\text { (Set aside courts) }\end{array}$ & Dutch Courts (Enforcement courts) & $\begin{array}{l}\text { UK Courts (Enfor- } \\
\text { cement courts) }\end{array}$ \\
\hline $\begin{array}{l}\text { The Russian court } \\
\text { denied enforce- } \\
\text { ment of the arbi- } \\
\text { tral awards based } \\
\text { on its violation of } \\
\text { the public policy } \\
\text { of the Russian } \\
\text { Federation. (1) }\end{array}$ & $\begin{array}{l}\text { The court reasoned that under the New } \\
\text { York Convention, a court requested to } \\
\text { enforce a foreign award is not compelled to } \\
\text { recognize a decision annulling that award } \\
\text { in the country of origin without examin- } \\
\text { ing whether the annulment decision meets } \\
\text { the private international law requirements } \\
\text { for being recognized in the enforce- } \\
\text { ment country. In the present case, it was } \\
\text { highly possible, even likely, that the Russian } \\
\text { annulment decisions had been rendered on } \\
\text { the instructions of the Russian executive } \\
\text { and the courts had not been impartial and } \\
\text { independent; therefore, those decisions } \\
\text { had no impact on enforcement. (2) }\end{array}$ & $\begin{array}{l}\text { The Court reasoned that in } \\
\text { the absence of authority it } \\
\text { is suggested that where an } \\
\text { award has been set aside by a } \\
\text { court of the seat, it should be } \\
\text { enforced only if recognition } \\
\text { of the setting aside decision } \\
\text { would be impeachable for } \\
\text { fraud or as being contrary to } \\
\text { natural justice, or otherwise } \\
\text { contrary to public policy. } \\
\text { The judge concluded that } \\
\text { an award that has been } \\
\text { annulled at the seat is still } \\
\text { in existence if the annul- } \\
\text { ment decision offends } \\
\text { "against basic principles } \\
\text { of honesty, natural justice } \\
\text { and domestic concepts } \\
\text { of public policy". (3) }\end{array}$ \\
\hline
\end{tabular}

(1) JAN VAN DEN BERG, Albert. Yearbook Commercial Arbitration. 2010, Vol.35, pp. 435-7.

(2) JAN VAN DEN BERG, Albert. Yearbook Commercial Arbitration. 2012, Vol.37, p. 313.

(3) JAN VAN DEN BERG, Albert. Yearbook Commercial Arbitration. 2014, Vol.39, pp. 528-30.

38 JAN VAN DEN BERG, Albert. Yearbook Commercial Arbitration. 2012, Vol.37, pp. 526-9.

39 JAN VAN DEN BERG, Albert. Yearbook Commercial Arbitration. 2010, Vol.35, pp. 435-7.

40 JAN VAN DEN BERG, Albert. Yearbook Commercial Arbitration. 2009, Vol.34, pp. 703-14.

41 JAN VAN DEN BERG, Albert. Yearbook Commercial Arbitration. 2010, Vol.35, pp. 423-6. 


\subsection{Supplementary data analysis of court decisions}

Occasional cases are certainly insufficient to evidence the serious confusion in enforcement proceedings of set-aside arbitral awards. An analysis of the above mentioned court decisions indicates that national courts generally interpreted article V 1(e) of the New York Convention, as they have discretion on whether to enforce set-aside arbitral awards and they are not bound by set-aside decisions made by foreign courts. However, such interpretation does not lead to inevitable enforcement of set-aside arbitral awards. The key issues here are (i) how likely is it that the enforcement courts will enforce arbitral awards that have been set aside by competent courts, and (ii) what is necessary to convince them to grant or refuse enforcement of set-aside awards?

This author searched all court decisions related to the 'set aside' issue under Article 1 (e) of the New York Convention published in ICCA Yearbook Commercial Arbitration (hereinafter, 'Yearbook') from 1977 to the date of writing in order to explore more complete and statistical evidence on enforcing set-aside arbitral awards. ${ }^{42}$ The Yearbook provides an annual update on court decisions on the New York Convention. Due to limitations and selectivity of the court decisions published in the Yearbook, the published court decisions may not present a representative dataset of the enforcement status of set-aside arbitral awards. However, the court decisions that are published in the Yearbook involve all provisions of the New York Convention and cover all jurisdictions governed by the Convention. Thus, the outcome of this research can be used to identify trends in the enforcement of set-aside arbitral awards at the international level. The total number of court decisions published in the Yearbook that relate to 'set aside' issues is approximately $125 .{ }^{43}$ Earliest court decisions mostly included controversies on issues such as which courts were competent courts, whether awards were successfully set aside and so on (approximate 50 decisions). This research further narrowed the dataset to court decisions that involved consideration of whether enforcement courts should enforce an arbitral award that had been successfully set aside in the country of origin and whether enforcement courts should stay enforcement proceedings pending setting aside actions. The dataset was narrowed to 63 court decisions.

Excluding duplicate and reversed lower courts' decisions, this research selected 49 decisions made by national courts of 13 states, including 12 decisions

42 The completed collection of Yearbook Commercial Arbitration from 1977 to date is recorded at KluwerArbitration.com, which is the world's leading online resource for international arbitration research. It also contains a wealth of commentary from expert authors and an extensive collection of primary source materials.

43 The amount of New York Convention court decisions came out related to the' topic 516: awards not binding, suspended or set aside: 'set aside" of in Kluwer Arbitration database was one hundred and twenty-five. This number was last checked on November 21, 2017. Some court decisions were made by courts at different layers on same case facts, thus were excluded afterwards. 
involving whether enforcement courts should suspend enforcement proceedings pending foreign setting aside actions. It is important to note that the comparatively small number of selected court decisions do not, in themselves, demonstrate that enforcement of set-aside arbitral awards is rare in practice. This limited number is notable when one considers that the number of published courts decisions on the Yearbook relating to the enforcement of international arbitral awards is also limited. Considering the miscount and finality of some court decisions, it is possible that these data are still inaccurate or incomplete. ${ }^{44}$ However, the selected court decisions, which date from 1975 to 2017, cover several major jurisdictions and include almost all important court decisions related to this issue in international arbitration history. Through data analysis, it is possible to identify the judicial approach taken in each jurisdiction that is studied, and to make an international comparison of those approaches. Most importantly, the data analysis undertaken in this research exposes how enforcement courts frequently review and ignore foreign set-aside decisions, and how it is very likely that arbitral awards are enforced even when they have been set aside in their country of origin.

First, whether or not an enforcement court chooses to suspend enforcement proceedings pending foreign setting aside actions is a poor indicator of whether enforcement courts are likely to grant or refuse enforcement after the arbitral award has been successfully set aside. In twelve decisions that involved parallel setting aside actions, enforcement courts enforced three arbitral awards (two in the United States and one in Germany), and suspended enforcement proceedings in nine decisions (one in the United Kingdom, three in the United States, four in the Netherlands and one in Austria). It is not unusual for enforcement courts to resume enforcement proceedings and grant enforcement even after an arbitral award has been set aside in its country of origin. ${ }^{45}$ Suspension of enforcement proceedings by enforcement courts is mainly based on a consideration of comity and in order to avoid parallel proceedings. For example, courts in the Netherlands suspended four enforcement proceedings, holding even though the foreign set-aside decisions are not binding in the Netherlands, they would be indicative, particularly because the defendant's grounds for refusing enforcement were the same as those for seeking the award's annulment in the country of origin. ${ }^{46}$ Enforcement judges felt obligated to make a comprehensive decision on

44 For example, the PEMEX decision made by United States Southern district of New York Court in 2013 had been appealed to and confirmed by the United States Court of Appeals, Second Circuit in 2016. See Corporación Mexicana de Mantenimiento Integral, S. de R.L. de C.V. v. PEMEX - Exploración y Producción, 832 F.3d 92 (2016).

45 For example, in PEMEX, New York District Court once suspended he enforcement proceeding pending set aside action, and then enforced the award after it had been set aside.

46 Abedian, Hossein. Judicial Review of Arbitral Awards in International Arbitration -A Case for an Efficient System of Judicial Review. Journal of International Arbitration, 2011, vol. 28, p. 553; Thadikkaran, Manu. Enforcement of Annulled Arbitral Awards: What Is and What Ought to Be? Journal of International Arbitration, 2014, p. 575. 
the enforcement by balancing procedural efficiency, merits of the arbitral awards and finality of dispute resolution. ${ }^{47}$ Interestingly, seven published suspension decisions were made after 2010, demonstrating it still needs time to verify final judicial decisions in relevant cases.

Out of other 37 court decisions involving enforcement of arbitral awards that have been successfully set aside, enforcement courts refused to enforce set-aside arbitral awards in 19 cases (51.4\%), applying Article V 1(e) of the New York Convention, and ignored foreign set-aside decisions in the remaining 18 cases (48.6\%). Some national courts showed great discretion in ignoring foreign setaside decisions. For example, according to Article 1520 and Article 1525 of the French Code of Civil Procedure, being set aside is not a ground for refusing enforcement. ${ }^{48}$ Therefore, in 7 French cases $(87.5 \%)$, the French courts enforced arbitral awards that had been set aside by competent courts based on the 'morefavorable-right' provision of Article VII of the New York Convention. In contrast, United States courts refused to enforce arbitral awards that had been set aside in 6 out of 9 decisions (66.7\%), based on Article V 1 (e) of the New York Convention. Detailed numbers and jurisdictions are presented in the following table.

\begin{tabular}{|c|c|c|}
\hline States & $\begin{array}{c}\text { Ignored foreign set side deci- } \\
\text { sions or actions }\end{array}$ & $\begin{array}{c}\text { Refuse to or suspend enforce } \\
\text { set-aside arbitral awards }\end{array}$ \\
\hline $\begin{array}{c}\text { United } \\
\text { Kingdom }\end{array}$ & [2014] Yukos Capital S.a.r.L v. & [2017] Nikolay Viktorovich Maximov v. \\
& OJSC Oil Company Rosneft (1) & Open Joint Stock Company “Novolip- \\
& & etsky Metallurgichesky Kombinat" (2) \\
& [2015] Malicorp Limited v. Government \\
& & of the Arab Republic of Egypt et al. (3) \\
& & Suspension \\
& & [2010] Continental Transfert Technique \\
& & Limited v. the Federal Government of Nigeria \\
& & \\
\hline
\end{tabular}

47 Jan Van Den Berg, Albert. Yearbook Commercial Arbitration. 2010, Vol.35, pp. 519-21.

48 Paulsson Jan, Bosman, Lise. ICCA International Handbook on Commercial Arbitration. 2011, Supplement No. 64, pp. 12-5. 
ICLR, 2018, Vol. 18, No. 1.

\begin{tabular}{|c|c|c|}
\hline France & $\begin{array}{l}\text { [2007] PT Putrabali Adyamulia (Indo- } \\
\text { nesia) v. Rena Holding, et al. (4) } \\
\text { [2007] S.A. Lesbats et Fils (France) } \\
\text { v. Dr. Volker Grub (Germany) (5) } \\
\text { [1997] Omnium de Traitement et de } \\
\text { Valorisation (OTV) v. Hilmarton (6) } \\
\text { [1997] The Arab Republic of Egypt v. } \\
\text { Chromalloy Aeroservices, Inc. (7) } \\
\text { [1994] Ministry of Public Works } \\
\text { v. Société Bec Frères (8) } \\
\text { [1993] Polish Ocean Line v. Jolasry (9) } \\
\text { [1984] Pabalk Ticaret Ltd. Sirketi } \\
\text { (Turkey) v. Norsolor SA (France) (10) }\end{array}$ & [1980] M. Claude Clair v. M. Louis Berardi (11) \\
\hline United States & $\begin{array}{l}\text { [2017] Corporación Mexicana de Man- } \\
\text { tenimiento Integral, S. de R.L. de C.V. v. } \\
\text { PEMEX - Exploración y Producción (12) } \\
\text { [2013] Yukos Capital s.a.r.l. v. } \\
\text { OAO Samaraneftegaz (13) } \\
\text { [1996] Chromalloy Aeroservices Inc. } \\
\text { v. The Arab Republic of Egypt (14) }\end{array}$ & $\begin{array}{c}\text { [2017] Thai-Lao Lignite (Thailand) Co., Ltd. } \\
\text { v. Lao People's Democratic Republic (15) } \\
\text { [2016] Getma International v. The } \\
\text { Republic of Guinea (16) } \\
\text { [2007] TermoRio S.A. E.S.P. (Colom- } \\
\text { bia), LeaseCo Group and others v. } \\
\text { Electranta S.P. (Colombia) (17) } \\
\text { [2006] Telcordia Technologies, Inc. (US) } \\
\text { v. Telkom SA Ltd. (South Africa) (18) } \\
\text { [1999] Martin I. Spier v. Calza- } \\
\text { turificio Tecnica SpA (19) } \\
\text { [1999] Baker Marine (Nig.) Limited v. Chev- } \\
\text { ron (Nig.) Limited, Chevron Corp. (20) } \\
\text { Suspension } \\
\text { [2016] Interdigital Communica- } \\
\text { tions, Inc., et al. v. Huawei Invest- } \\
\text { ment \& Holding Co., Ltd, et al. } \\
\text { [2016] Hulley Enterprises Ltd. et } \\
\text { al. v. The Russian Federation } \\
\text { [1988] Gesco Ltd. (nationality not indi- } \\
\text { cated) v. Han Yang Corporation (Korea) }\end{array}$ \\
\hline Germany & $\begin{array}{c}\text { [2012] Ukrainian dealer v. Ger- } \\
\text { man manufacturer (21) } \\
\text { [2007] Company A (Austria) v. } \\
\text { Company B (Austria) (22) } \\
\text { Enforcement whiles set aside actions } \\
\text { [2008] Not indicated v. Not indicated (23) }\end{array}$ & $\begin{array}{c}\text { [2007] Supplier (US) v. State enter- } \\
\text { prise (Belarus) (24) } \\
\text { [1999] Not indicated v. Not indicated (25) }\end{array}$ \\
\hline
\end{tabular}

Published by Palacký University Olomouc, Czech Republic, 2018.

ISSN (print): 1213-8770; ISSN (online): 2464-6601 


\begin{tabular}{|c|c|c|}
\hline Netherlands & $\begin{array}{l}\text { [2012] Kompas Overseas Inc. v. OAO } \\
\text { Severnoe Rechnoe Parokhodstvo (North- } \\
\text { ern River Shipping Company) (26) } \\
\text { [2009] Yukos Capital s.a.r.l. (Luxembourg) } \\
\text { v. OAO Rosneft (Russian Federation) (27) }\end{array}$ & $\begin{array}{c}\text { [2016] Nikolai Viktorovich Maximov v. OJSC } \\
\text { Novolipetsky Metallurgichesky Kombinat (28) } \\
\text { [2009] Imanagement Services Ltd. } \\
\text { (British Virgin Islands) v. çuku- } \\
\text { rova Holding A.S. (Turkey) (29) } \\
\text { [1975] Société Européenne d'Etudes et } \\
\text { d'Enterprises (S.E.E.E.) v. Federal Republic of } \\
\text { Yugoslavia, Supreme Court (Hoge Raad) (30) } \\
\text { Suspension } \\
\text { [2015] Econet Wireless Limited } \\
\text { v. Bharti Airtel Nigeria BV. } \\
\text { [2012] Sonera Holding B.V. v. } \\
\text { Çukurova Holding A.S. } \\
\text { [2012] Frener \& Reifer Russia LLC } \\
\text { v. Enka Insaat Ve Sanayi A.S. } \\
\text { [2011] Danish Polish Telecommunications } \\
\text { Group I/S v. Telecommunikacja Polska SA. }\end{array}$ \\
\hline Brazil & $\begin{array}{l}\text { [2012] YPFB Andina S/A v. UNI- } \\
\text { VEN Petroquímica Ltda (31) }\end{array}$ & $\begin{array}{l}\text { [2015] EDF International S/A v. } \\
\text { Endesa Latinoamérica S/A (32) }\end{array}$ \\
\hline $\begin{array}{l}\text { Russian } \\
\text { Federation }\end{array}$ & $\begin{array}{l}\text { [2011] Ciments Français v. Holding } \\
\text { Company Sibirskiy Cement OJSC (33) }\end{array}$ & - \\
\hline Switzerland & - & $\begin{array}{l}\text { [1985] Continaf BV (Netherlands) v. } \\
\text { Polycoton SA (Switzerland) (34) }\end{array}$ \\
\hline Australia & - & $\begin{array}{c}\text { Suspension } \\
\text { [2015] Johnson Ye v. Ronghuo Zeng } \\
\text { (a/k/a Andrew Tsang) et al. }\end{array}$ \\
\hline Spain & $\begin{array}{c}\text { [1996] Actival Internacional SA } \\
\text { v. Conservas El Pilar SA (35) }\end{array}$ & - \\
\hline Chile & - & $\begin{array}{l}\text { [2011] EDF Internacional SA v. (1) Endesa } \\
\text { Latinoamericana SA, (2) YPF SA (36) }\end{array}$ \\
\hline Luxembourg & - & $\begin{array}{l}\text { [2017] PEMEX - Exploracion y Produc- } \\
\text { cion v. Corporacion Mexicana de Manten- } \\
\text { imiento Integral, S. de R.L. de C.V. (37) }\end{array}$ \\
\hline $\begin{array}{l}\text { Hong Kong, } \\
\text { China }\end{array}$ & - & $\begin{array}{l}\text { [2016] Dana Shipping and Trad- } \\
\text { ing SA v. Sino Channel Asia Ltd }\end{array}$ \\
\hline Total Number & 21 & 28 (Suspension:9) \\
\hline
\end{tabular}

Table footnotes:

(1) JAN VAN DEN BERG, Albert. Yearbook Commercial Arbitration. 2014, Vol. 39, pp. 525.

(2) JAN VAN DEN BERG, Albert. Yearbook Commercial Arbitration. 2017, Vol. 42, pp. 1-43.

(3) JAN VAN DEN BERG, Albert. Yearbook Commercial Arbitration. 2016, Vol. 41, pp. 585.

(4) JAN VAN DEN BERG, Albert. Yearbook Commercial Arbitration. 2007, Vol. 32, pp. 299-302.

(5) JAN VAN DEN BERG, Albert. Yearbook Commercial Arbitration. 2007, Vol. 32, pp. 297-8.

(6) JAN VAN DEN BERG, Albert. Yearbook Commercial Arbitration. 1997, Vol. 22, pp. 696-8.

(7) JAN VAN DEN BERG, Albert. Yearbook Commercial Arbitration. 1997, Vol. 22, pp. 691-5.

(8) JAN VAN DEN BERG, Albert. Yearbook Commercial Arbitration. 1997, Vol. 22, pp. 682-90.

(9) JAN VAN DEN BERG, Albert. Yearbook Commercial Arbitration. 1994, Vol. 19, pp. 662-3.

(10) JAN VAN DEN BERG, Albert. Yearbook Commercial Arbitration. 1986, Vol. 11, pp. 484-91.

(11) JAN VAN DEN BERG, Albert. Yearbook Commercial Arbitration. 1982, Vol. 7, pp. 319.

(12) JAN VAN DEN BERG, Albert. Yearbook Commercial Arbitration. 2013, Vol. 38, pp. 537-41.

(13) JAN VAN DEN BERG, Albert. Yearbook Commercial Arbitration. 2015, Vol. 40, pp. 520-4.

(14) JAN VAN DEN BERG, Albert. Yearbook Commercial Arbitration. 1997, Vol. 22, pp. 1001-12. 
(15) JAN VAN DEN BERG, Albert. Yearbook Commercial Arbitration. 2017, Vol. 42, pp. 1-29.

(16) JAN VAN DEN BERG, Albert. Yearbook Commercial Arbitration. 2017, Vol. 42, pp. 10.

(17) JAN VAN DEN BERG, Albert. Yearbook Commercial Arbitration. 2008, Vol. 33, pp. 955-69.

(18) JAN VAN DEN BERG, Albert. Yearbook Commercial Arbitration. 2007, Vol. 32, pp. 810-21.

(19) JAN VAN DEN BERG, Albert. Yearbook Commercial Arbitration. 2000, Vol. 25, pp. 1042-56.

(20) JAN VAN DEN BERG, Albert. Yearbook Commercial Arbitration. 1999, Vol. 24, pp. 909-14.

(21) JAN VAN DEN BERG, Albert. Yearbook Commercial Arbitration. 2014, Vol. 39, pp. 394-8.

(22) JAN VAN DEN BERG, Albert. Yearbook Commercial Arbitration. 2008, Vol. 33, pp. 517-28.

(23) JAN VAN DEN BERG, Albert. Yearbook Commercial Arbitration. 2009, Vol. 34, pp. 522-6.

(24) JAN VAN DEN BERG, Albert. Yearbook Commercial Arbitration. 2009, Vol. 34, pp. 504-9.

(25) JAN VAN DEN BERG, Albert. Yearbook Commercial Arbitration. 2000, Vol. 25, pp. 641-1164.

(26) JAN VAN DEN BERG, Albert. Yearbook Commercial Arbitration. 2012, Vol. 37, pp. 277-81.

(27) JAN VAN DEN BERG, Albert. Yearbook Commercial Arbitration. 2009, Vol. 34, pp. 703.

(28) JAN VAN DEN BERG, Albert. Yearbook Commercial Arbitration. 2017, Vol. 42, pp. 38.

(29) JAN VAN DEN BERG, Albert. Yearbook Commercial Arbitration. 2009, Vol. 34, pp. 733-5.

(30) JAN VAN DEN BERG, Albert. Yearbook Commercial Arbitration. 1976, Vol. 1, pp. 195-8.

(31) JAN VAN DEN BERG, Albert. Yearbook Commercial Arbitration. 2013, Vol. 38, pp. 341-3.

(32) JAN VAN DEN BERG, Albert. Yearbook Commercial Arbitration. 2016, Vol. 41, pp. 415.

(33) JAN VAN DEN BERG, Albert. Yearbook Commercial Arbitration. 2011, Vol. 36, pp. 325-8.

(34) JAN VAN DEN BERG, Albert. Yearbook Commercial Arbitration. 1987, Vol. 12, pp. 505-9.

(35) JAN VAN DEN BERG, Albert. Yearbook Commercial Arbitration. 2002, Vol.27, pp. 528-32.

(36) JAN VAN DEN BERG, Albert. Yearbook Commercial Arbitration. 2016, Vol. 41, pp. 441.

(37) JAN VAN DEN BERG, Albert. Yearbook Commercial Arbitration. 2017, Vol. 42, pp. 13.

Examination on these 37 court decisions exposes how all the enforcement courts scrutinized set-aside decisions that had been made by foreign courts and compared set aside grounds of the foreign states with their own national legislation. All enforcement decisions ( 18 of $37,48.6 \%$ ) were made based on the assertion that enforcement of relevant arbitral awards did not violate the national legislation of the enforcement states. ${ }^{49}$ The 'more-favorable-right' provision of the New York Convention was the most commonly quoted legal source in all enforcement decisions. More specifically, as highlighted above, French Courts made all enforcement decisions based on the 'more-favorable-right' provision and French Code of Civil Procedure, Article 1520 (7 of 18).$^{50}$ Additionally, United States, German and Dutch courts made three enforcement decisions based on the 'more-favorable-right' provision of the New York Convention (one in Germany, one in United States one in the Netherlands, 3 of 18). Three enforcement decisions ignored foreign set-aside decisions, based mainly on public policy considerations (one in the United Kingdom, two in the United States, 3 of 18). Two enforcement decisions relied on the 1961 European Convention, which does not provide for violation of public policy and non-arbitrability as grounds for setting aside arbitral awards (one in Germany, one in the Russian Federation, 2 of 18). ${ }^{51}$ In one case, Dutch judges ignored a foreign set-aside decision based on possible

49 See Yukos Capital S.a.r.L v. OJSC Oil Company Rosneft, in JAN VAN DEN BERG, Albert. Yearbook Commercial Arbitration. 2012, Vol.37, p. 313.

50 JAN VAN DEN BERG, Albert. Yearbook Commercial Arbitration. 2007, Vol.32, pp. 299-302.

51 See Ukrainian dealer v. German manufacturer and Ciments Français v. Holding Company Sibirskiy Cement OJSC. 
violation of due process. In two court decisions, enforcement judges ignored foreign setting aside proceedings, manifesting that contradictory decisions can be reached in enforcement and setting aside proceedings in different states (one in Brazil and one in Spain). The proportions of each type of reasoning model used in these 18 court decisions are now presented in following chart.

Reasoning models of these enforcement decisions are complex and multilayered. The common approach that can be concluded from these court decisions is that enforcement judges tend to compare grounds for setting aside arbitral awards applied in foreign set-aside decisions with those provided in enforcement states. Additionally, Enforcement courts review both foreign set-aside decisions and arbitral awards by considering a number of aspects, including grounds of foreign set-aside decisions, national legislation, international rules, and international public policy. Even in the cases where national courts eventually refused enforcement of arbitral awards that had been set aside, national courts were intent on undertaking a detailed judicial review on foreign set-aside decisions rather than refusing enforcement immediately in accordance with Article V 1 (e) of the New York Convention.

Most states have both granted and refused enforcement of several awards that have been set aside in their country of origin. In most cases, the involved parties had experienced inconsistent national judicial proceedings before obtaining the final decision. For example, in the case of PEMEX, which is still under development at the time of writing, COMMISA sought a declaration of enforceability of the award in Luxembourg, and they obtained an order granting leave of exequatur of the award from the Luxembourg District Court on March 22, 2013. However, on April 21, 2017, the Eighth Chamber of the Court of Appeal finally annulled the decision and refused the enforcement based on the premise that an award that has been set aside in its country of rendition cannot be granted recognition and enforcement under the 1958 New York Convention. The same award was enforced by the United States court of appeal, second circuit, on August 2, 2016. Although the reasoning of the Luxembourg appellant court, and its approach to its enforcement decision, was clear and explicit, the national enforcement proceedings in Luxembourg took upwards of eight years. Most other states intend to vacillate seriously on the issue of enforcing set-aside awards. The inconsistent approaches taken by national courts greatly lengthens and complicates enforcement proceedings. Parallel and opposing enforcement proceedings gradually eroded the effectiveness and finality of international arbitration. Balancing fairness and efficiency is never easy in dispute resolutions; forming a consistent international approach must be a priority for developing a modern arbitration regime. 
Noticeably, even though the level of these enforcement decisions does not present a prevailing trend, a number of enforcement courts from different jurisdictions, by coincidence, propose similar approaches in their decisions: 'although the enforcement court has the discretion to enforce a set-aside award, it should not exercise that discretion unless the annulment decision offends the fundamental principles of public policy and natural justice., ${ }^{52}$ One can find similar wording in recent (post-2015) decisions from the United States, Australia, Hong Kong, the United Kingdom and the Netherlands. ${ }^{53}$ Several decisions have explicitly restricted the judicial review on foreign set-aside decisions by examining where there is a violation of 'international public policy. ${ }^{54}$ Specifically, Dutch courts applied due process standards, provided in Art. 6 of the European Convention on Human Rights (ECHR), to justify whether or not there was a violation. Adopting the developing norm of 'international public policy' has greatly unified national judicial practice and decreased the frequency of enforcing setaside arbitral awards.

\section{Challenges and opportunities}

Both the comparison of legal sources and real court decision data demonstrate that the enforcement of set-aside arbitral awards is a worldwide ongoing controversy. Due to inconsistent set aside grounds and ambiguous legal sources, the practical enforcement of set-aside arbitral awards results in a confusing and inefficient situation that contrasts to traditional set-aside theory. Enforcement judges are accustomed to expanding judicial review on both foreign set-aside decisions and arbitral awards. Enforcement proceedings become increasingly complicated and lengthy due to parallel setting aside proceedings and relevant challenges in enforcement proceedings. Setting aside proceedings and court decisions are utilized as obstacles in promoting enforcement of international arbitral awards. Parties are forced to re-negotiate and settle at the post-award stage, avoiding inefficient enforcement proceedings and unpredictable results. The following section addresses possible solutions.

\subsection{Revising the New York Convention}

As the most efficient mechanism to regulate international commercial arbitration, the New York Convention is considered to be the ultimate resolution to many problems in international arbitration. One scholar notes that chaotic enforcement of set-aside arbitral awards is caused mainly by ambiguous wording that is used in Article V of the New York Convention; revising relevant provi-

52 JAN VAN DEN BERG, Albert. Yearbook Commercial Arbitration. 2016, Vol.41, pp. 585.

53 See Scherer, supra note 11.

54 Lalive, Pierre. Transnational (or Truly International) Public Policy and International Arbitration. in Sanders, Pieter (ed). Comparative Arbitration Practice and Public Policy in Arbitration. 1987, p. 257; Hunter, Martin, Gui, Gonde. Transnational Public Policy and its Application in Investment Arbitrations. J.W.I., 2003, vol. 4, p.367. 
sions would, therefore, offer an immediate solution to this problem. ${ }^{55}$ In numerous proposals for revising the New York Convention or for establishing a new convention, ${ }^{56}$ one of the most important efforts has been led by Professor Albert Jan van den Berg. ${ }^{57}$ Van den Berg's draft makes relevant revisions and supplements to the most controversial problems exposed in the New York Convention. On enforcement of set-aside arbitral awards, he proposes revising Article V1 (e) to the following:

Enforcement of an arbitral award shall be refused if, at the request of the party against whom the award is invoked, that party asserts and proves that:

(g) the award has been set aside by the court in the country where the award was made on grounds equivalent to grounds (a) to (e) of this paragraph; or... ${ }^{58}$

Briefly, he proposes that the New York Convention requires national courts to refuse enforcement of set-aside arbitral awards. However, his draft opens another opportunity for enforcement courts to review set-aside decisions made by foreign courts. Accordingly, only those set-aside decisions based on grounds (a) to (e) are required to be respected by enforcement courts. This revision indicates that the biggest concern for enforcement courts is that the grounds used for foreign set-aside decisions are not supported by their national provisions. A good example is that violation of public policy is not provided for as a ground for setting aside arbitral awards in Article IX of the European Convention of 1961; thus, foreign set-aside decisions based on violation of public policy would not be recognized by some enforcement courts in its signatories. ${ }^{59}$ If the New York Convention provides exclusive grounds for setting aside arbitral awards, enforcement courts are more likely to follow foreign set-aside decisions. Therefore, whether to establish a strict primary jurisdiction seems irrelevant because all enforcement courts tend to review set-aside decisions. Only those decisions made based on grounds recognized by enforcement states will be respected. Thus, the key resolution leads to grounds for setting aside arbitral awards.

55 See Bird, supra note 19, p. 1039, n.179.

56 See generally SHEN, Wei. Rethinking the New York Convention: a law and economics approach. Cambridge: Intersentia, 2013; See Bird, supra note 19, p. 1039, n.179.

57 JAN VAN DEN BERG, Albert. Hypothetical Draft Convention on the International Enforcement of Arbitration Agreements and Awards' [online, hereinafter van den Berg, Draft Convention] Available <http:// www.arbitration-icca.org/media/0/12133674097980/ hypothetical_draft_convention_ajbrev06.pdf > Accessed: 27. Nov. 2017.

58 JAN VAN DEN BERG, Albert. A Closer Look at the Proposed "New New York Convention" [online, hereinafter van den Berg, Proposed 'New New York Convention'] Global Arb. Rev., 2008, vol. 3, p. 19, Available <http://www.arbitration-icca.org/media/1/13318252772820/ new_ny_conv.pdf> Accessed 27. Nov. 2017.

59 JAN VAN DEN BERG, Albert. Should the Setting Aside of the Arbitral Award be Abolished? ICSID Review, 2014, p. 12. 


\subsection{Co-ordinated national legislation and judicatory practice}

Some commentators have asserted that, even though the New York Convention is silent on grounds for setting aside arbitral awards, it implies that such grounds should be identical with grounds for refusing enforcement. ${ }^{60}$ This assertion is also made in Berg's draft convention. ${ }^{61}$ By applying parallel grounds for setting aside arbitral awards, national courts are able to set aside or enforce arbitral awards more consistently. To some extent, revising relevant international provision is comparatively easy; the most difficult aspect is to unify national legislation and judicatory practice. For example, although the prevailing view is that the New York Convention provides exclusive grounds for national courts in signatory states to refuse recognition and enforcement of arbitral awards, ${ }^{62}$ national courts will inevitably and unsurprisingly approach and determine controversial issues in accordance with their own national laws and procedures. ${ }^{63}$ More controversially, court decisions may also be influenced by local legal, cultural, economic, and political systems. While many jurisdictions provide extra grounds for refusing enforcement to complement the New York Convention, courts from signatory states tend to believe it to be their own responsibility to fit all their national grounds for refusing enforcement of international arbitral awards into the framework of the New York Convention. ${ }^{64}$

Therefore, revising international provisions and applying parallel grounds for setting aside arbitral awards is the first step in resolving contradictory enforcement proceedings of set-aside arbitral awards. With international and national legislation becoming increasingly uniform, co-ordinating national judicatory practice is an essential mean of securing a promising outcome. Professor Berg suggested establishing an international body who has exclusive jurisdiction to set aside an arbitral award to eliminate this complex question. ${ }^{65}$ With this idea is still developing, there are many things we can do at both international and national level.

The effectiveness of national implementation can be enhanced by several approaches. The United Nations Commission on International Trade Law (UNCITRAL), as the core legal body of the United Nations system in the field of international trade law and the drafter of the New York Convention and UNCITRAL Model Law, is capable of playing a more competent role in monitoring

60 JAN VAN DEN BERG, Albert. The New York Arbitration Convention of 1958. Kluwer Law and Taxation Publishers, 1981, p. 330; Lillich, Richard B., Brower, Cahrles N. International arbitration in the 21st century: Towards "Judicialization" and Uniformity. Transnational Publishers, 1992, p. 38.

61 See Berg, supra note 57.

62 See Berg, supra note 60, p. 327.

63 Lew, Julian D M. Does National Court Involvement Undermine the International Arbitration Process? Am. U. Int'l L. Rev., 2009, vol. 24, p. 489.

64 See Berg, supra note 60.

65 See Berg, supra note 59, p. 25. 
the implementation situation of the New York Convention in national legal systems. Even though it lacks authority to intervene in related national legislation and judicatory, there are several measures that can be taken to produce positive impacts. First, the UNCITRAL Model Law was published to provide guidelines to national arbitration legislation and successfully harmonize many national provisions. Second, the UNCITRAL Secretariat has established a system for col-

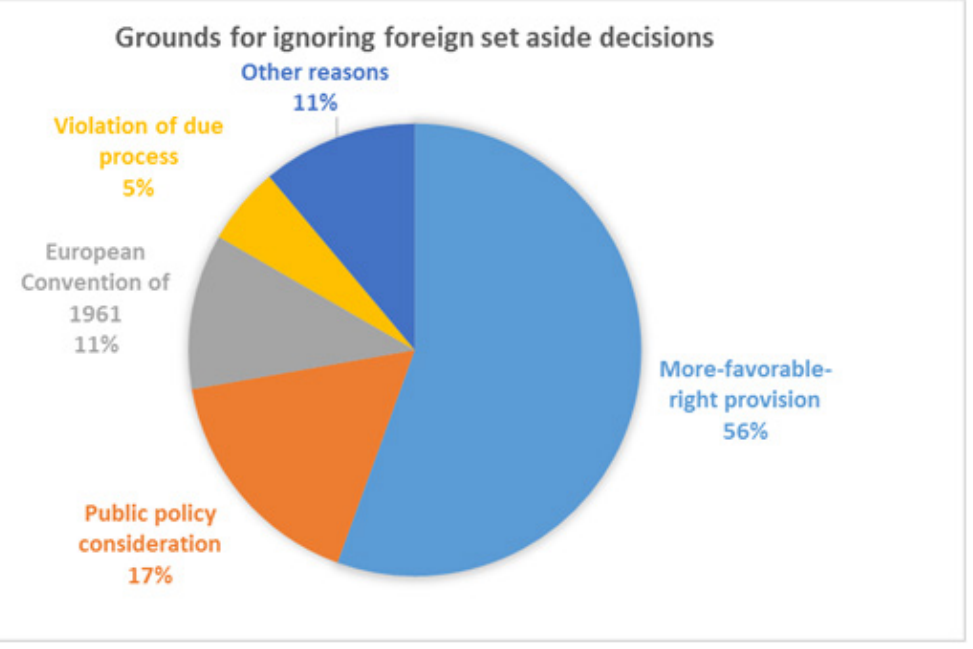

lecting and disseminating information on court decisions and arbitral awards related to the Conventions and Model Laws (CLOUT cases). ${ }^{66}$ The purpose of this system is to promote international awareness of the legal texts formulated by the Commission and to facilitate uniform interpretation and application of those texts. This case digest system works as a good starting point to assess judicatory status in different states. If relevant national legislations and detailed evaluations are added to the existing case collections, this system may develop into an efficient tool to monitor the implementation situation of relevant international provisions. It can also help build the implementation reputation of different states. It may promote further national legislation and judicatory revisions. Some states have been considered to be arbitration-unfriendly places for a long time. Reporting more arbitration-favorable and internationalized legislations and court decisions may alter the community's negative impressions and attract more arbitration business. Third, numerous commission reports, working documents, and other academic projects undertaken by UNCITRAL or by other international groups provide an authoritative reference to national judicatory. It is less likely that national courts are still stubborn in applying governing international provisions in an inconsistent way with their official interpretations.

66 UNCITRAL. Case Law on UNCITRAL Texts (CLOUT). [online]. Available $<$ http://www. uncitral.org/uncitral/en/case_law.html> Accessed: 1. Nov. 2017. 
Inside national legal systems, majority of nations' same choice of promulgating and formalizing arbitration statutes indicates that codified arbitration legislations have taken a predominant and superior role in regulating international arbitration. ${ }^{67}$ In common law systems, especially the United States, there is a gap between arbitration statutes and relevant case law. U.S. judges are used to applying or creating case law to supplement statutory provisions, which receives massive criticisms and produces a lot of confusion. ${ }^{68}$ The doctrine of "manifest disregard of law" is a good example. The "manifest disregard of law" doctrine originated in the Supreme Court's decisions in Wilko and First Option, where the Court decisions implied that arbitral awards could be set aside if arbitrators manifest disregard of applicable law. One commentator described the manifest disregard of law doctrine as such: "much has been made of the brief excerpt from Wilko, turning it from an unexplained comment into a widely-cited authority with no support in the statutory scheme." ${ }^{69}$ Although being frequently used as an argument to set aside arbitral awards, "manifest disregard of law" seldom works out in practice. ${ }^{70}$ Therefore, cleaning up or limiting mere case law rules is another aspect in which the national legal system can work to improve its efficiency. Judges can also make rules on the issues that are not covered by arbitration statutes, but such authority should be limited and performed in accordance with the spirit of national and international arbitration laws.

In addition, in a purely judicatory aspect, national judicatory systems are built on different kinds of regimes. In some states, the Supreme Court has more centralized power for supervising lower national courts, while other states have less centralized court systems. Based on existing national court regimes, increasing consistency in judicatory practice will improve the implementation of both national and international rules. Consistent judicatory practice can be enhanced through an arbitration case reporting system in a more centralized court regime, such as the Chinese People's Supreme Court requiring any denial of the application of the New York Convention and setting aside decisions for international arbitral awards to be reported to and reviewed by the Supreme Court. ${ }^{71}$

67 For example, on March 25, 2008, the U.S. Supreme Court issued its ruling in Hall Street Associates LLC v. Mattel, Inc., stating that the standards for judicial review of an arbitral award set forth in Sections 10 and 11 of the Federal Arbitration Act ("FAA") are exclusive and may not be expanded by contract, which potentially rebutted all common law grounds for vacating arbitral awards. Hall Street Associates, L.L.C. v. Mattel, Inc., 128 S. Ct. 1396 (U.S. 2008). See also Kerr, Michael. The Arbitration Act 1979. Modern Law Review, 1980, vol. 43 , p.1.

68 See also Scodro, Michael. Deterrence and Implied Limits on Arbitral Power. Duke L. J., 2005, vol. 55, p.567.

69 Ibid.

70 P. O’Mullan, Michael. Note, Seeking Consistency in Judicial Review of Securities Arbitration: An Analysis of the Manifest Disregard of the Law Standard. Fordham L. Rev., 1995, vol. 64, p.1124.

71 Notice of the SPC Concerning the Handling of Foreign-Related Arbitration and Foreign Arbitration, Fa Fa [1995]No. 18. 
In conclusion, the divergence between national legislation and international rules has to be harmonized through rectifying inconsistent national legislations and restraining case law sources. Additionally, judicatory practice should be guided to perform in a more consistent and effective way in implementing international and national law. Due to the limitations of this article, discussion on this issue will not be further expanded here.

\section{Conclusion}

There is a wealth of empirical evidence to demonstrate that the nullity effect of set-aside decisions at the international level is impractical due to difficulties in requiring that enforcement courts recognize decisions made by foreign courts, especially when these decisions are made based on national standards that are not provided by enforcement states. Such difficulties are rooted in the fact that enforcements courts commonly hold that they are not bound by set-aside decisions that have been made by foreign courts due to ambiguous legal sources and different national grounds for setting aside arbitral awards. Although recent empirical data further exposes how increasing numbers of enforcement judges assert that their discretion to enforce set-aside arbitral awards is limited to rare circumstances when relevant foreign set-aside decisions violated fundamental justice or 'international public policy,' enforcement of set-aside arbitral awards is still an ongoing and controversial issue. Inconsistent and capricious national approaches make enforcement proceedings unduly complicated and inefficient, severely impeding the effectiveness of the enforcement regime established under the framework of the New York Convention. Many commentators propose to revise the New York Convention to address the contradictory enforcement proceedings of set-aside arbitral awards. Rather than revising international law to reconfirm the vanishing set-aside authority, this author argues that effort should be directed towards the establishment of international uniform set aside grounds and the co-ordination of national legislation and judicatory practice.

\section{References}

Abedian, Hossein. Judicial Review of Arbitral Awards in International Arbitration -A Case for an Efficient System of Judicial Review. Journal of International Arbitration, 2011, vol. 28, p. 553.

Berger, Klaus Peter. Private Dispute Resolution in International Business: Negotiation, Mediation, Arbitration. Kluwer Law International, 2015.

Bird, Robert C. Enforcement of Annulled Arbitration Awards: A Company Perspective and an Evaluation of a "New" New York Convention. N.C. J. Int'l L. \& Com. Reg., 2012, vol. 37, p. 1028.

Chukwumerije, Okezie. Choice of Law in International Commercial Arbitration. 1994.

Derains, Yves, Schwarts, Eric A. A guide to the new ICC rules of Arbitration. Kluwer Law International, 2005.

Dunmore, Michael. Chapter III: The Award and the Courts, Enforcement of Awards 
Set Aside in their Jurisdiction of Origin', in Klausegger, Christian, Klein, Peter, et al. (eds). Austrian Yearbook on International Arbitration 2014. 2014.

GAILLARD, Emmanuel, Savage, John (eds.). Fouchard, Gaillard, Goldman, On International Commercial Arbitration, 1999.

Gaillard, E. The Enforcement of Awards Set Aside in the Country of Origin. ICSID Rev., 1999, vol. 14, p.16.

Graham, Trotman/M. Nijhoff, The Internationalisation of International Arbitration: The LCIA Centenary Conference. Graham \& Trotman/M. Nijhoff,, 1995.

Hunter, Martin, Gui, Gonde. Transnational Public Policy and its Application in Investment Arbitrations. J.W.I., 2003, vol. 4, p.367.

Jan Van Den Berg, Albert. Yearbook Commercial Arbitration. 1976-2017.

Jan Van Den Berg, Albert. Enforcement of arbitral awards annulled in Russia. Journal of International Arbitration, 2010, vol. 27, p.179.

JAN VAN DEN BERG, Albert. Hypothetical Draft Convention on the International Enforcement of Arbitration Agreements and Awards' [online, hereinafter van den Berg, Draft Convention] Available <http:// www.arbitration-icca.org/ media/0/12133674097980/hypothetical_draft_convention_ ajbrev06.pdf > Accessed: 27. Nov. 2017.

JAN VAN DEN BERG, Albert. A Closer Look at the Proposed "New New York Convention" [online, hereinafter van den Berg, Proposed 'New New York Convention'] Global Arb. Rev., 2008, vol. 3, p. 19, Available <http://www.arbitration-icca. org/media/1/13318252772820/new_ny_conv.pdf > Accessed 27. Nov. 2017.

JAN VAN DEN BERG, Albert. Should the Setting Aside of the Arbitral Award be Abolished? ICSID Review, 2014, p. 12.

JAN VAN DEN BERG, Albert. The New York Arbitration Convention of 1958. Kluwer Law and Taxation Publishers, 1981.

Koch, Christopher. The Enforcement of Awards Annulled in their Place of Origin: The French and US experience. J. Int'l Arb., 2009, vol. 26, p.292.

Kerr, Michael. The Arbitration Act 1979. Modern Law Review, 1980, vol. 43, p.1.

Scodro, Michael. Deterrence and Implied Limits on Arbitral Power. Duke L. J., 2005, vol. 55 , p. 567.

Lastenouse, Pierre. Why Setting Aside an Arbitral Award is not Enough to Remove it from the International Scene. Journal of International Arbitration, 1999, vol. 16, p. 25.

Lalive, Pierre. Transnational (or Truly International) Public Policy and International Arbitration. in Sanders, Pieter (ed). Comparative Arbitration Practice and Public Policy in Arbitration. 1987.

Lillich, Richard B., Brower, Cahrles N. International arbitration in the 21st century: Towards "Judicialization" and Uniformity. Transnational Publishers, 1992.

Lew, Julian D M. Does National Court Involvement Undermine the International Arbitration Process? Am. U. Int'l L. Rev., 2009, vol. 24, p. 489.

Mann, F.A., Arbitrum, Lex Facit. International Arbitration: Liber Amicorum for Martin Domke. 1967.

Paulsson, J. Enforcing Arbitral Awards notwithstanding a Local Standard Annulment (LSA). ICC International Court of Arbitration Bulletin, 1998, vol. 9, no. 1, p.14.

Park, W. Duty and Discretion in International Arbitration. Am J. Int'l L., 1999, vol. 93, p. 805. 
Paulsson, Jan, Bosman, Lise. ICCA International Handbook on Commercial Arbitration. 1994-2015.

P. O’Mullan, Michael. Note, Seeking Consistency in Judicial Review of Securities Arbitration: An Analysis of the Manifest Disregard of the Law Standard. Fordham L. Rev., 1995, vol. 64, p. 1124.

Poudret, Jean-François, Besson, Sébastien. Comparative Law of International Arbitration. Sweet \& Maxwell, 2007.

PARK, William W. Judicial Controls in the Arbitral Process. Arb. Int'l. 1989, vol.5 p.279.

PARK, William W. The Lex Loci Arbitri and International Commercial Arbitration. I.C.L.Q., 1983, vol. 32, p. 2.

Reisman, W. Michael. System of Control in International Adjudication and Arbitration Breakdown and Repair. Duke University Press Durham and London, 1992.

Redfern, Hunter. Redfern and Hunter on International Arbitration. Oxford University Press, 5th Ed., 2009.

Rubino-Sammartano, Mauro. International Commercial Arbitration. Kluwer Law and Taxation Publishers, 1990.

Read, Pippa. Delocalization of International Commercial Arbitration: It's Relevance in the New Millennium. Am. Rev. Int'l Arb., 1999, vol. 10, p. 186.

Radicati di Brozolo, Luca G. The Present-Commercial Arbitration as a Transnational System of Justice, in Jan Van Den Berg, Albert (ed). Arbitration: the Next Fifty Years, ICCA Congress Series. Kluwer Law International, 2012, p. 96.

Scodro, Michael A. Deterrence and Implied Limits on Arbitral Power. Duke L. J., 2005, vol. 55, p. 557.

Scherer, Maxi. The Effect of Foreign National Court Judgments Relating to the Arbitral Award: An Emerging Conceptual Framework? in Menaker, Andrea (ed). International Arbitration and the Rule of Law: Contribution and Conformity. Kluwer Law International, 2017, pp. 691-705.

SHEN, Wei. Rethinking the New York Convention: a law and economics approach. Cambridge: Intersentia, 2013.

Thadikkaran, Manu. Enforcement of Annulled Arbitral Awards: What Is and What Ought to Be? Journal of International Arbitration, 2014, p. 575.

UNCITRAL. Case Law on UNCITRAL Texts (CLOUT). [online]. Available <http:// www.uncitral.org/uncitral/en/case_law.html> Accessed: 1. Nov. 2017. 